\title{
Evaluation of indoor environmental quality with limited surface sampling for metals at an office building
}

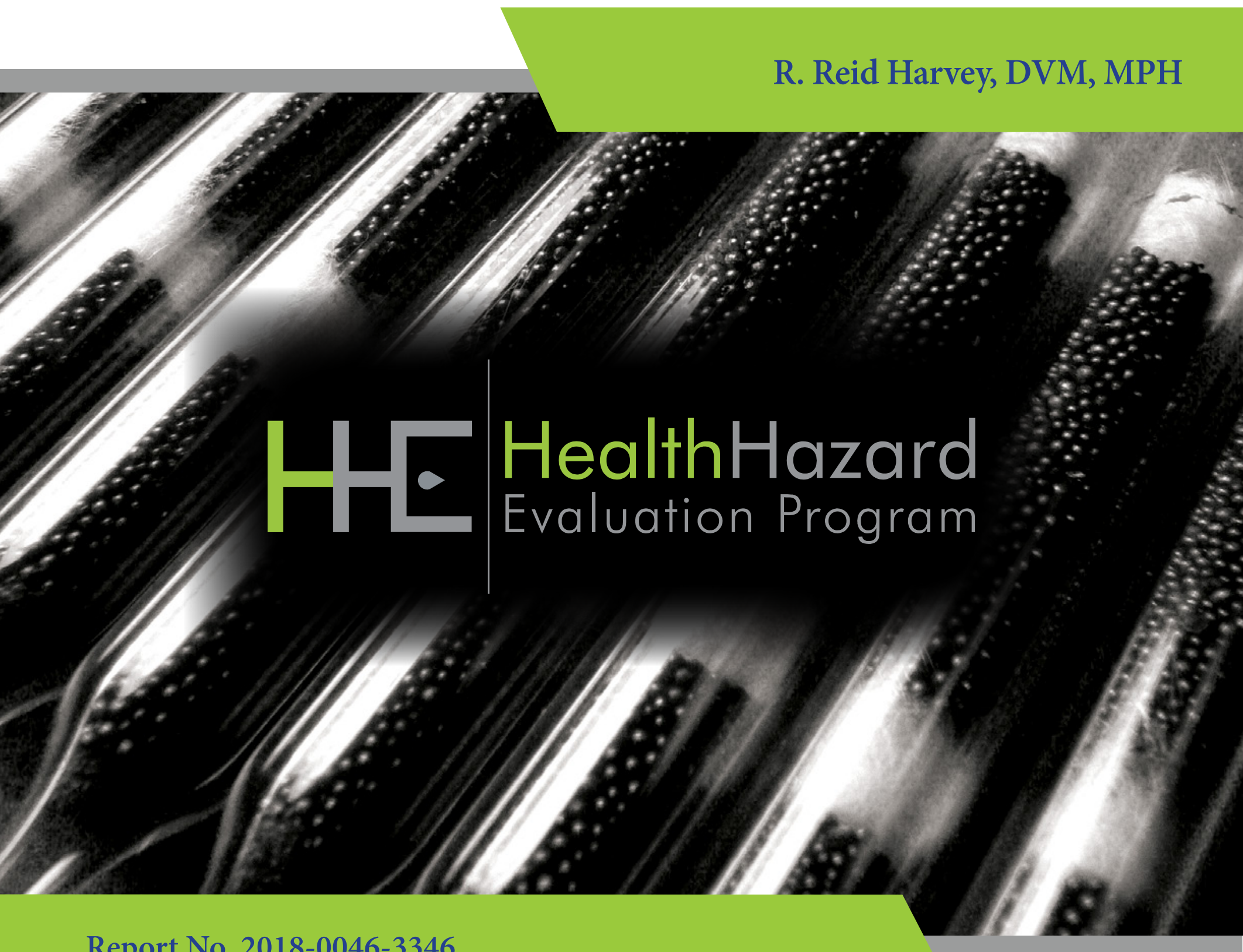

March 2019

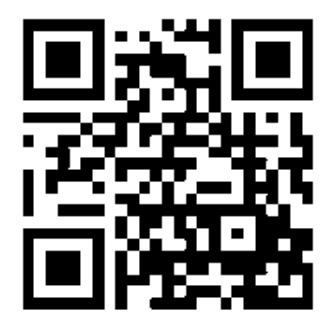

U.S. Department of Health and Human Services Centers for Disease Control and Prevention

National Institute for Occupational Safety and Health

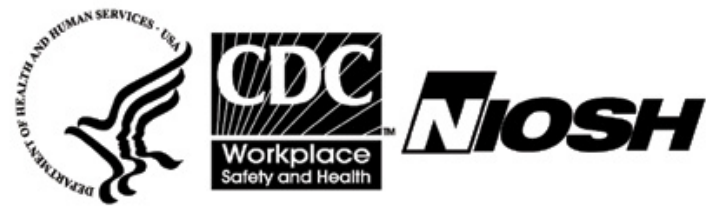




\section{Contents}

Highlights. i

Abbreviations ..................................... iv

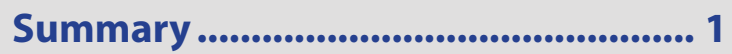

Introduction ........................................... 2

Background............................................. 2

Methods ............................................... 2

Results .................................................. 6

Discussion .............................................. 7

Conclusions........................................ 17

Recommendations............................ 17

Appendix A: Table............................... 19

Appendix B: Figures ........................... 20

References............................................. 22

Acknowledgements.......................... 29

The employer is required to post a copy of this report for 30 days at or near the workplace(s) of affected employees. The employer must take steps to ensure that the posted report is not altered, defaced, or covered by other material.

The cover photo is a close-up image of sorbent tubes, which are used by the HHE Program to measure airborne exposures. This photo is an artistic representation that may not be related to this Health Hazard Evaluation. 


\section{Highlights of this Evaluation}

The Health Hazard Evaluation Program of the National Institute for Occupational Safety and Health (NIOSH) received a request from the union representing employees working in an office building. Employees were concerned about the air quality throughout the building. Employee health concerns included breathing issues; eye irritation; skin lesions, and allergy attacks that they attributed to dampness and mold in the building and particulates from the heating, ventilation, and air-conditioning system.

\section{What We Did}

- We evaluated the office building on June 1, 2018.

- We held an opening meeting with management and union representatives.

- We took wipe samples of particulates for metals on surfaces of the heating, ventilation, and air-conditioning system and office furniture.

\section{What We Found}

- We observed areas with evidence of indoor dampness and rodents, and an improperly functioning heating, ventilation, and airconditioning system.

- Management reported receiving notifications regularly from employees that fragrances in the workplace caused mucous membrane or respiratory symptoms.

- Although the particulates sampled from around the supply air vents and office furniture were positive for a number of metals, our limited sampling could not determine if metals present on surfaces were from metals historically used to manufacture jewelry at this building.

We assessed indoor
environmental quality
and performed limited
environmental surface sampling
for metals present in dust
samples collected at an office
building previously used to
manufacture jewelry. During
our walkthrough, we identified
a number of potential concerns
regarding indoor environmental
quality, including signs of
indoor dampness, dust, rodents,
and an improperly functioning
heating, ventilation, and air-
conditioning system. Samples of
particulates collected from the
areas near the supply air vents
contained metals. However, our
limited sampling of dust could
not determine if metals present
on surfaces were from metals
historically used to manufacture
jewelry at this building.

\section{What the Employer Can Do}

- Create a health and safety committee consisting of employees who work throughout the building to engage with management on issues such as comfort (temperature and relative humidity), indoor dampness, dusty environments, housekeeping concerns, and fragrances. 
- Review personal workspace rules and enforcement guidelines that apply to blocking vents; food storage, preparation, and consumption areas; refrigerators; fish tanks; dehumidifiers; and fragrances.

- Encourage employees to report new, persistent, or worsening symptoms, particularly those with a work-related pattern, to their healthcare providers and, as instructed by their employer, to a designated individual at their workplace.

\section{What Employees Can Do}

- Follow your employer's rules about personal workspaces. Store, prepare, and consume food in appropriate and designated places; do not block vents.

- Follow any workplace policies related to refrigerators, fish tanks, dehumidifiers, and fragrances.

- Report comfort concerns (temperature and relative humidity) to the designated individual at your workplace to resolve the concerns before adjusting your workspace temperature and relative humidity.

- Report new, persistent, or worsening respiratory symptoms to your personal healthcare provider(s) and a designated individual at your workplace. 
This page left intentionally blank 


\section{Abbreviations}

$\begin{array}{ll}\mu g & \text { Micrograms } \\ \text { ACGIH } & \text { American Conference of Governmental Industrial Hygienists } \\ \mathrm{cc} / \mathrm{min} & \text { Cubic centimeters per minute } \\ \mathrm{cfm} & \text { Cubic feet per minute } \\ \mathrm{EPA} & \text { U.S. Environmental Protection Agency } \\ \mathrm{ft} 2 & \text { Square feet } \\ \text { HEPA } & \text { High-efficiency particulate air } \\ \text { HVAC } & \text { Heating, ventilation, and air-conditioning } \\ \text { IARC } & \text { International Agency for Research on Cancer } \\ \text { IDLH } & \text { Immediately dangerous to life or health } \\ \text { mg/m3 } & \text { Milligrams per cubic meter } \\ \text { mL } & \text { Milliliters } \\ \text { NAICS } & \text { North American Industry Classification System } \\ \text { NIOSH } & \text { National Institute for Occupational Safety and Health } \\ \text { OEL } & \text { Occupational exposure limit } \\ \text { OSHA } & \text { Occupational Safety and Health Administration } \\ \text { PEL } & \text { Permissible exposure limit } \\ \text { ppm } & \text { Parts per million } \\ \text { REL } & \text { Recommended exposure limit } \\ \text { TLV } & \text { Threshold limit value } \\ \text { VOC } & \text { Volatile organic compound }\end{array}$




\section{Summary}

In December 2017, the National Institute for Occupational Safety and Health's Health Hazard Evaluation Program received a request from the union representing employees working in an office building. Employees were concerned about air quality throughout the building. Employee health concerns included breathing issues; eye irritation; skin lesions, and allergy attacks that they attributed to dampness and mold in the building, and particulates from the heating, ventilation, and air-conditioning systems. Employees were concerned about particulates from the heating, ventilation, and air-conditioning system supply air vents. Specifically, employees were concerned the heating, ventilation, and air-conditioning system contained residual particulates with metals from when the building was used to manufacturer jewelry roughly 30 years ago. On June 1, 2018, we performed a walkthrough of the office building and performed wipe sampling to analyze particulates for metals found on office furniture and in areas near the heating, ventilation, and air-conditioning system supply air vents.

During our walkthrough, we identified a number of potential issues related to indoor environmental quality at this office building, some of which were caused by retrofitting an industrial building into an office building. Indoor environmental quality issues included signs of a dusty environment, indoor dampness, improperly functioning heating, ventilation, and air-conditioning system, and rodents and pests. Management reported receiving notifications regularly from employees that fragrances in the workplace caused mucous membrane or respiratory symptoms. We recommend creating a health and safety committee consisting of employees who work throughout the building to engage with management on issues such as comfort (temperature and relative humidity), indoor dampness, dusty environments, and housekeeping concerns. We recommend management review personal workspace rules and enforcement guidelines pertaining to blocking vents; food storage, preparation, and consumption areas; refrigerators; fish tanks; dehumidifiers; and fragrances. 


\section{Introduction}

In December 2017, the Health Hazard Evaluation Program of the National Institute for Occupational Safety and Health (NIOSH) received a request from a union representing employees at an office building who were concerned about potential exposures related to the air quality throughout the building. Employee concerns included indoor dampness and mold. Employees were also concerned that particulates from the heating, ventilation, and air-conditioning (HVAC) system contained metals used in jewelry manufacturing, given the historical use of the building. The union cited health concerns including breathing problems, allergies, eye irritation, and skin lesions. On June 1, 2018, we performed a walkthrough of the building and performed wipe sampling to analyze particulates from the HVAC system for metals.

\section{Background}

Before becoming an office building in the early 1990s, the building was used to manufacture jewelry. NIOSH conducted a health hazard evaluation in the building in 1993 following abrasive blasting of indoor lead-based paint [NIOSH 1994]. No airborne lead was detected. Wipe samples detected lead levels as high as 200,000 micrograms of lead per square feet $(\mu \mathrm{g} /$ $\mathrm{ft} 2$ ). Although there are no federal guidelines for surface lead exposure, NIOSH investigators concluded there were potential lead exposure opportunities for employees, primarily through ingestion, and recommended lead abatement and follow-up air sampling. Given the unique history of the building being used for jewelry manufacturing, and union member concerns including metal exposure, specifically from particulates from the HVAC system, we conducted a walkthrough of the building and performed limited environmental surface sampling on June 1, 2018.

\section{Methods}

\section{Walkthrough}

Our objectives during the walkthrough of the facility were to evaluate the building, gather information on the HVAC system, assess for signs of indoor dampness and pests, and discuss previous renovations and routine cleaning procedures. We were provided floor plans for each of the five floors. Participants on the walkthrough of the building included NIOSH investigators and representatives from management, building ownership, and the union.

\section{Wipe sampling}

We performed limited environmental sampling on all five floors of the building. We conducted wipe sampling of particulates on or around (i.e., nearby furniture surfaces) the HVAC supply air vents on each floor. The objective of the wipe sampling was to measure metals present in the dust in the HVAC system and compare with metals commonly found in jewelry manufacturing.

We used GhostWipes ${ }^{\mathrm{TM}}$ to collect loose dust from the surfaces surrounding the HVAC 
system using single-use 10 -centimeter $\times 10$-centimeter template for each sample collected. We collected four wipe samples on each floor for a total of 20 samples, coinciding roughly with zones A-D as most floors were divided into these four zones. These wipe samples were analyzed for metals, using a standard method with our contract laboratory. The panel examined the wipe samples for metals including aluminum, antimony, arsenic, barium, beryllium, cadmium, calcium, chromium, cobalt, copper, indium, iron, lanthanum, lead, lithium, magnesium, manganese, molybdenum, nickel, phosphorus, potassium, selenium, silver, strontium, tellurium, thallium, titanium, vanadium, yttrium, zinc, and zirconium.

The samples were analyzed for elements according to NIOSH Method 7303 [NIOSH 2003]. Each wipe sample was placed in a clean 50 milliliter $(\mathrm{mL})$ polypropylene centrifuge tube. Next $2.0 \mathrm{~mL}$ of 15.6 molar nitric acid was added to each tube. Then $6.0 \mathrm{~mL}$ of 12.1 molar hydrochloric acid was added to each tube and placed in a hot block and heated at a temperature of $95^{\circ} \mathrm{C}$. Samples were observed during the digestion. Small quantities of deionized water were added to the samples that demonstrated signs of moving up the tubes. The samples were digested in the hot block for 45 minutes. The samples were removed from the hot block, cooled, and diluted to a final volume of $25 \mathrm{~mL}$ with deionized water. All samples, limit of detection spikes, and quality control samples were digested in the same manner.

The following elements have known background levels present in GhostWipe ${ }^{\mathrm{TM}}$ media: aluminum ( 1-3 micrograms [ug]), calcium ( 40-50 ug), copper ( 1-3 ug), iron ( 2-7 ug), magnesium (up to $130 \mathrm{ug}$ ), phosphorous ( 10-25 ug), potassium ( 10-35 ug), tin ( 1-2 ug), and zinc $(\sim 35-60 \mathrm{ug})$. Seven media blanks associated with this sequence were prepared and analyzed on media provided to the laboratory. The samples have been blank corrected with the media blank average. Elements detected in the media blanks above the limit of detection included arsenic (6.2ug), barium (0.071ug), calcium (18ug), magnesium (15ug), manganese ( $0.13 \mathrm{ug})$, molybdenum $(0.052 \mathrm{ug})$, phosphorous ( $37 \mathrm{ug})$, potassium $(90 \mathrm{ug})$, strontium $(0.092 \mathrm{ug})$, and zinc (44ug). Iron was also detected but at levels too low to quantify.

\section{Exposure Limits}

We use mandatory (legally enforceable) and recommended occupational exposure limits (OELs) when evaluating workplace hazards. OELs have been developed by federal agencies and safety and health organizations to prevent adverse health effects from workplace exposures.

\section{Occupational Safety and Health Administration (OSHA) [Mandatory]}

The U.S. Department of Labor's OSHA permissible exposure limits (PELs) are legal limits that are enforceable in workplaces covered under the Occupational Safety and Health Act. OSHA PELs represent the legal maximum for a time weighted average (TWA) exposure to a physical or chemical agent over a work shift [OSHA 2018]. OSHA short-term exposure limits (STELs) are the legal maximum average exposure for a 15-minute time period. Some chemicals also have an OSHA ceiling value which represent levels that must not be exceeded at any time. For substances for which an OSHA PEL has not been issued, violation of the OSHA General Duty Clause can be considered using available occupational 
exposure references and recommendations [OSHA 1993; OSHA 2003], such as the American Conference of Governmental Industrial Hygienists $\left(\mathrm{ACGIH}^{\circledR}\right)$ Threshold Limit Values $\left(\right.$ TLVs $\left.^{\circledR}\right)$ and NIOSH RELs.

American Conference of Governmental Industrial Hygienists (ACGIH) [Recommendations] ACGIH is a professional, not-for-profit scientific association that reviews existing published, peer-reviewed scientific literature and publishes recommendations for levels of substances in air based on an 8-hour workday and 40-hour workweek. These recommendations are called threshold limit values (TLVs) [ACGIH 2018]. ACGIH TLVs are not standards; they are health-based guidelines derived from scientific and toxicological information. ACGIH provides TLV-TWA guidelines that are levels that should not be exceeded during any 8-hour workday of a 40-hour workweek. ACGIH also provides TLV-STEL guidelines which are 15-minute exposure levels that should not be exceeded during a workday. Exposures above the TLV-TWA but less than the TLV-STEL should be (1) less than 15 minutes, (2) occur no more than four times a day, and (3) be at least 60 minutes between exposures [ACGIH 2018]. Additionally, ACGIH provides TLV-Ceiling values which are levels that should not be exceeded at any time during a work shift.

National Institute for Occupational Safety and Health (NIOSH) [Recommendations] NIOSH provides RELs as TWA concentrations that should not be exceeded over an 8 or 10-hour work shift, during a 40-hour workweek [NIOSH 2010]. RELs are intended to be protective over a 45-year working lifetime. NIOSH also provides STELs which are 15-minute TWA exposures that should not be exceeded at any time during a workday [NIOSH 2010]. Some chemicals have ceiling values which are concentrations that should not be exceeded at any time [NIOSH 2010]. For some chemicals, NIOSH has established an Immediately Dangerous to Life or Health (IDLH) value. An IDLH value is a concentration of an air contaminant that can cause death or immediate or delayed permanent adverse health effects, or prevent escape from such an environment.

Table 1 below provides a summary of OELs for metals found on the wipe samples collected [OSHA 2018; ACGIH 2018; NIOSH 2010]. However, in each case, the OELs are only applicable for airborne concentrations of the metal particulates. When compared to each other, these limits provide some information on the relative toxicity of the individual metal species, but the limits are not meant to be directly applied to wipe samples from settled surface dust. There are no OSHA, NIOSH, or ACGIH exposure limits for any of the metals collected from surface samples. 
Table 1. Exposure limits for compounds sampled during the NIOSH survey, June 2018

\begin{tabular}{|c|c|c|c|c|}
\hline \multirow[b]{2}{*}{ Compound } & \multirow{2}{*}{\begin{tabular}{|l} 
OSHA \\
PEL \\
$\left(\mathrm{mg} / \mathrm{m}^{3}\right)$
\end{tabular}} & ACGIH & \multicolumn{2}{|c|}{ NIOSH } \\
\hline & & $\begin{array}{l}\text { TLV } \\
\left(\mathrm{mg} / \mathrm{m}^{3}\right)\end{array}$ & $\begin{array}{l}\text { REL } \\
\left(\mathrm{mg} / \mathrm{m}^{3}\right)\end{array}$ & $\begin{array}{l}\text { IDLH } \\
\left(\mathbf{m g} / \mathbf{m}^{3}\right)\end{array}$ \\
\hline Aluminum (total dust) & 15 & 1 & 10 & - \\
\hline Antimony & 0.5 & 0.5 & 0.5 & 50 \\
\hline Arsenic (inorganic) [ca] & - & 0.01 & $0.002(\mathrm{C})$ & 5 \\
\hline Barium sulfate (total dust) & 15 & 5 & 10 & 50 \\
\hline Beryllium [ca] & 0.002 & 0.00005 & 0.0005 & 4 \\
\hline Cadmium [ca] & 0.005 & 0.01 & - & 9 \\
\hline Calcium hydroxide (total dust) & 15 & 5 & 5 & 25 (oxide) \\
\hline Chromium metal & 1 & 0.5 & 0.5 & 250 \\
\hline Cobalt metal, dust, and fume & 0.1 & 0.02 & 0.05 & 20 \\
\hline Copper dusts and mists & 1 & $\begin{array}{l}0.2 \text { (fume) } \\
1 \text { (dusts and mists) }\end{array}$ & 1 & 20 \\
\hline Iron oxide & 10 & 5 & 5 & 2,500 \\
\hline Lanthanum & - & - & - & - \\
\hline Lead (inorganic) & - & 0.05 & 0.05 & 100 \\
\hline Lithium hydride & 0.025 & $0.05(\mathrm{C})$ & 0.025 & 0.5 \\
\hline Magnesium oxide fume & 15 & 10 & - & 750 \\
\hline Manganese & $5(\mathrm{C})$ & 0.1 (IHL) & 1 & 500 \\
\hline Molybdenum (total dust) & 15 & $\begin{array}{l}10 \text { (IHL) } \\
3 \text { (Resp) }\end{array}$ & - & 5,000 \\
\hline Nickel (metal)[ca] & 1 & $\begin{array}{l}0.1 \text { (soluble inorganic } \\
\text { compounds, IHL) } \\
0.2 \text { (insoluble inorganic } \\
\text { compounds, IHL) } \\
1.5 \text { (elemental, IHL) }\end{array}$ & 0.015 & 10 \\
\hline Phosphorus (yellow) & 0.1 & 0.1 & 0.1 & 5 \\
\hline Potassium & - & - & - & - \\
\hline Selenium & 0.2 & 0.2 & 0.2 & 1 \\
\hline Silver (metal) & 0.01 & $\begin{array}{l}0.01 \text { (soluble compounds) } \\
0.1 \text { (metal, dust, and fume) }\end{array}$ & 0.01 & 10 \\
\hline Strontium & - & - & - & - \\
\hline Tellurium & 0.1 & 0.1 & 0.1 & 25 \\
\hline Thallium & 0.1 & 0.02 (IHL) & 0.1 & 15 \\
\hline Tin (inorganic) & 2 & 2 & 2 & 100 \\
\hline Titanium dioxide (total dust) [ca] & 15 & 10 & $0.3-2.4$ & 5,000 \\
\hline Vanadium, respirable dust & $0.5(\mathrm{C})$ & 0.05 (IHL) & $0.05(\mathrm{C})$ & 35 \\
\hline Yttrium & 1 & 1 & 1 & 500 \\
\hline Zinc oxide (total dust) & 15 & 2 (resp) & 5 & 500 \\
\hline Zirconium & 5 & 5 & 5 & 25 \\
\hline
\end{tabular}

Note: OSHA=Occupational Safety and Health Administration; ACGIH=American Conference of Governmental Industrial Hygienists; NIOSH=National Institute for Occupational Safety and Health; $P E L=$ permissible exposure limit; $T L V=$ threshold limit value; $R E L=$ recommended exposure limit; IDLH=immediately dangerous to life or health; $\mathbf{m g} / \mathrm{m}^{3}=$ milligram per cubic meter of air; $\mathrm{C}=$ ceiling limit; ca=potential carcinogen; $\mathrm{IHL}=$ inhalable; Resp=respirable; "__"=no exposure limit available. 


\section{Results}

\section{Walkthrough}

We evaluated all five floors of the building, and the roof and basement. An atrium that spanned all five floors was located in the middle of the building. The atrium was constructed during the retrofitting of the building from jewelry manufacturing to office space. Floors two through five housed office space for employees. The second floor had a 24-hour call center that was always staffed by employees. The first floor had some office space but also had rooms visited by the public and a small café.

The floor plan varied among floors but was mostly open. The office space was divided according to employee teams rather than an even distribution of offices and cubicles throughout the building; areas of concentrated workspaces (mostly cubicles) and other areas that were sparse or used only for storage were present. During our walkthrough, we observed many personal refrigerators, microwaves, houseplants, and fish bowls occupying individual workspaces or areas. Management reported receiving notifications regularly from employees that myriad fragrances in the workplace caused mucous membrane or respiratory symptoms. There were narrow dead spaces around the perimeter of the building that contained rodent traps where employees had previously observed rodents. Overall, there were few drop ceilings, and the HVAC system was largely visible throughout the facility. We noted several HVAC supply vents that were blocked or partially covered above workspaces by employees to change air movement in the area (Figure B1). Management reported receiving approximately five emails daily regarding employee comfort, primarily regarding temperature. Black dust was visible on the HVAC system throughout the facility (Figure B2). On the $3^{\text {rd }}$ floor, a fan belt had failed roughly one month before our evaluation causing excessive particulates to escape through the seam of the HVAC system. Some cubicles were covered with poster board under the vents to block dust from accumulating on desks (Figure B3). There were signs of recent water damage on an interior wall of the $5^{\text {th }}$ floor (Figure B4) and in the corner of the records room of the $2^{\text {nd }}$ floor; the leaks had been repaired. Management reported having leaks repaired in a timely fashion.

There were no recent major renovations according to management, but the rooms open to the public on the first floor were recently repainted. The carpets throughout the building were replaced approximately two years ago. Management reported that during the workday, there was one janitor performing basic housekeeping duties, but most cleaning was performed during the evening by a separate cleaning crew.

\section{Wipe sampling}

Detailed results of the wipe sampling are located in the Table in Appendix A. Although no clear pattern was identified, the $3^{\text {rd }}$ floor had the highest measured value for $19(70 \%)$ of 27 metals that were identified through sampling. The highest average metals per sample were calcium $(1,115 \mu \mathrm{g} / \mathrm{sample}$; range: $46-5,800 \mu \mathrm{g} / \mathrm{sample})$, iron (903 $\mu \mathrm{g} /$ sample; range: 0-6,900 $\mu \mathrm{g} /$ sample), and zinc (691 $\mu \mathrm{g} /$ sample; range: $0-5,200 \mu \mathrm{g} /$ sample $)$.

Other metals of note include aluminum (201 $\mu \mathrm{g} / \mathrm{sample}$; range: 0-790 $\mu \mathrm{g} / \mathrm{sample})$, copper 
(21 $\mu \mathrm{g} / \mathrm{sample;} \mathrm{range:} \mathrm{0-240} \mu \mathrm{g} / \mathrm{sample})$, lead (20 $\mu \mathrm{g} / \mathrm{sample}$; range: 0-160 $\mu \mathrm{g} / \mathrm{sample}$ ), titanium ( $6.8 \mu \mathrm{g} / \mathrm{sample}$; range: $0-41 \mu \mathrm{g} / \mathrm{sample})$, and manganese $(6.0 \mu \mathrm{g} / \mathrm{sample}$; range $0-33 \mu \mathrm{g} / \mathrm{sample})$. Also, comparatively lower levels of chromium ( $2.6 \mu \mathrm{g} / \mathrm{sample}$; range: $0-16$ $\mu \mathrm{g} / \mathrm{sample})$, nickel ( $1.9 \mu \mathrm{g} / \mathrm{sample}$; range: $0-10 \mu \mathrm{g} / \mathrm{sample})$, antimony $(0.8 \mu \mathrm{g} / \mathrm{sample}$; range: $0-9.2 \mu \mathrm{g} / \mathrm{sample})$, tin $(0.5 \mu \mathrm{g} / \mathrm{sample}$; range $0-12 \mu \mathrm{g} / \mathrm{sample})$, and silver $(0.4 \mu \mathrm{g} / \mathrm{sample}$; range: $0-3.3 \mu \mathrm{g} / \mathrm{sample}$ ) were detected.

No arsenic, beryllium, tellurium, or thallium were detected in the wipe samples. Other metals found in the samples were not known to be commonly used in jewelry manufacturing and included macroelements (phosphorus, magnesium, and potassium), trace minerals (selenium, cobalt, and molybdenum), and other metals with low average concentration (barium, cadmium, lanthanum, lithium, strontium, vanadium, yttrium, and zirconium).

\section{Discussion}

\section{Wipe sampling}

Pollutants found in dust can originate from interior or exterior sources and can include heavy metals, pesticides, polychlorobiphenyls, and polycyclic aromatic hydrocarbons [Tran et al. 2012]. Heavy metals in dust can enter the body through ingestion, inhalation, and skin contact [Al-Rajhi et al. 1996]. The International Agency for Research on Cancer (IARC) has classified arsenic, beryllium, cadmium, chromium, and nickel, as known human carcinogens [IARC 2018]. IARC has listed lead as probably carcinogenic to humans [IARC 2018]. Furthermore, arsenic, cadmium, chromium, and lead are considered widespread environmental contaminants [Sanborn et al. 2002]. Carcinogenic effects can include respiratory illnesses, cardiovascular deaths, and damage to the nervous system [Faiz et al. 2009]. Heavy metal concentration in indoor-dust can vary greatly between geographic locations and even rooms, and depends on surrounding industries [Lioy et al. 2002; Hassan 2012]. Wind-blown dust from surface soil and road dust were the main contributors of heavy metal contents found in indoor dust [Latif et al. 2014]. Some metals, such as cobalt, chromium, and nickel can also serve as skin sensitizers leading to contact allergy and dermatitis [Kettelarij et al. 2016].

The objective of the wipe sampling was to characterize the metals present on surfaces near the supply air vents. We aimed to determine if it was possible that an unknown depository of metals observed in jewelry manufacturing in or around the building could be disturbed and enter the HVAC system of the building and subsequently be deposited in the black dust surrounding the HVAC system throughout the building.

We provided the results from all metals analyzed for completeness (Table A1). However, we note no NIOSH or OSHA OELs exist for surface wipe samples for any of the metals analyzed in the surface dust. Therefore, we cannot determine if any samples are 'elevated' because there are no 'normal' or expected values. Many of the metals included on the panel are not used in jewelry manufacturing and can be found in many different environmental sources. These metals are widespread in nature, which makes their presence in the particulates we 
sampled unsurprising. In fact, many of the elements are nutritionally essential for healthy function of the brain and organs in larger (macro) or lesser (micro or trace) quantities. Macroelements or minerals on the panel include calcium, phosphorus, magnesium, and potassium. Microelements or trace minerals include iron, copper, manganese, zinc, selenium, cobalt, molybdenum, and chromium [MedlinePlus 2015]. The macro or microelements calcium, iron, and zinc had the highest average concentration. Other potential environmental exposures from many of these metals outside of dietary sources include cookware, medications, dental amalgams, fertilizers, fungicides, batteries, and household cleaning agents.

Metals used in jewelry manufacturing can be individual elements or alloys (mixtures of various elements) created by jewelers to change the color, melting temperature, or strength of the final product. Metals used in jewelry manufacturing are generally considered base metals or precious metals. Precious metals are rare and of high economic value (i.e., gold, platinum, and silver), and base metals are all other metals used in jewelry manufacturing [Rings \& Things 2018]. Silver is the only precious metal on the panel, however there are many metals that could be used as base metals or in alloys including aluminum, antimony, cadmium, copper, chromium, iron, nickel, lead, manganese, tin, titanium, and zinc.

Many metals used as base metals or in alloys in jewelry manufacturing also have other sources in the environment. Chromium, copper, iron, and zinc are used in jewelry manufacturing as alloys; however, they are also trace minerals and therefore can have multiple sources outside of jewelry manufacturing. For the other metals commonly used in jewelry manufacturing with unknown or inconclusive roles in human processes, we explored the relative concentrations and other potential sources to determine if metals from jewelry manufacturing were the likely source of the HVAC dust. Antimony, cadmium, manganese, nickel, tin, and titanium were all less than $7 \mu \mathrm{g} /$ sample on average. Antimony levels as high as $9.7 \mu \mathrm{g} / \mathrm{L}$ have been reported in drinking water, and food can also contain small amounts of antimony [ATSDR 2017]. Manganese occurs naturally in most foods and is also used in a wide variety of other products such as paint and cosmetics [ATSDR 2012]. Food is the major source of nickel; however, stainless steel and coins also contain nickel. Nickel in drinking water is between 2 parts per billion (ppb) and $4.3 \mathrm{ppb}(1 \mathrm{ppb}=1 \mu \mathrm{g} / \mathrm{L})$ on average, and soil contains between 4 parts per million $(\mathrm{ppm})$ and $80 \mathrm{ppm}(1 \mathrm{ppm}=1 \mu \mathrm{g} / \mathrm{mL})$ [ATSDR 2005]. Tin is present in the air, water, soil, and landfills; tin concentrations in food is generally less than 2 ppm unless packaged in metal cans containing tin [ATSDR 2005b]. Titanium is frequently used as a white pigments for paint, paper, inks, and plastics [DigitalFire 2015]. Cadmium can be used in jewelry making and cause kidney or respiratory disease, but also accumulates in leafy vegetables, plants, and tobacco [Wittman et al. 2002].

Aluminum can be used in jewelry manufacturing but has other potential environmental sources. Aluminum averaged $201 \mu \mathrm{g} / \mathrm{sample}$ with a maximum of $790 \mu \mathrm{g}$. Aluminum is found in consumer products including antacids (up to $208 \mathrm{mg}$ ), buffered aspirin (up to $20 \mathrm{mg}$ ), and cosmetics $(1 \mathrm{mg}=1,000 \mu \mathrm{g})$ [ATSDR 2008]. Lead averaged $20 \mu \mathrm{g} / \mathrm{sample}$, with a maximum of $160 \mu \mathrm{g}$. Wipe samples during the 1993 health hazard evaluation were as high as 200,000 $\mu \mathrm{g} / \mathrm{ft}^{2}$, or approximately $21,500 \mu \mathrm{g} / 100 \mathrm{~cm}^{2}$. Lead was the only metal sampled in 1993 
following extensive abrasive blasting to remove lead-based paint from the interior of the building [NIOSH 1994]. The highest wipe sample of lead detected in the current sampling is approximately 135 times lower than the highest sample from the 1993 sampling. The use of lead in products has been reduced in recent years to minimize lead's harmful effect [ATSDR 2007].

Of all the metals analyzed in the panel, silver would likely be the most useful to meet the objective of determining if there is an ongoing source of metals used in jewelry manufacturing that resulted in contaminated dust coming from the HVAC system. Silver is a precious metal used extensively in jewelry manufacturing. However, we observed low concentrations of silver in our wipe sampling $(0.4 \mu \mathrm{g} / \mathrm{sample}$ on average $)$ compared with other metals less frequently used in jewelry manufacturing. Furthermore, most people are exposed daily to low levels of silver in food and drinking water (up to $80 \mathrm{ppb}$ ), and less in the air [ATSDR 1990].

We observed many types of metals present on surfaces near supply air vents. Because many of the metals sampled are also present in dietary sources, drinking water, medications, cleaning agents, pigments, plastics, and other environmental sources, we were unable to determine if the metals observed on surfaces were from jewelry manufacturing that had previously occurred in the building.

\section{Dampness in Buildings}

We saw evidence of recent water damage during the walkthrough. We also observed potential sources of water in individual workspaces such as fish tanks. Research has found that damp building conditions can lead to respiratory illnesses in occupants. Dampness in buildings can occur for a variety of reasons such as high indoor humidity, condensation, and roof leaks. Damp building conditions promote the growth of mold, bacteria, and other microbial agents, as well as dust mites and cockroaches. Dampness can also contribute to the breakdown of building materials and furniture. Musty odors are a sign of microbial contamination. Building occupants in damp buildings can be exposed to pollutants in the air from biological contaminants and the breakdown of building materials.

\section{Building-related Symptoms}

Comprehensive reviews have been conducted of previous scientific studies evaluating the development of health effects associated with exposures from damp indoor conditions. The findings include associations with upper and lower respiratory symptoms, asthma development and exacerbation, hypersensitivity pneumonitis, respiratory infections, allergic rhinitis, bronchitis, and eczema [Mendell et al. 2011; WHO 2009]. NIOSH published an Alert, Preventing Occupational Respiratory Disease from Exposures Caused by Dampness in Office Buildings, Schools, and Other Nonindustrial Buildings, on respiratory disease related to indoor dampness and provides recommendations for preventing and remediating damp buildings [NIOSH 2012].

Air Sampling

NIOSH does not typically recommend air sampling for mold with building air quality 
evaluations. There are no U.S. health-based exposure limits for biological contamination set by OSHA or recommended by NIOSH. Measurements of mold in air are highly variable and dependent on the mold species' lifecycle stages (e.g., spore formation) [NIOSH 2012]. In many cases, short-term sampling for mold spores is conducted; however, the results might not be representative of actual exposures. Furthermore, spore counts and culture results, which tend to be what are included in indoor air quality reports, do not capture the full range of exposures. What building occupants react to is largely unknown. It can be mold, a compound produced by mold, something related to bacteria, or compounds that are released into the air when wet building materials break down. We have found visual inspections or detection of problem areas via musty odors are more reliable. These methods have been used in past NIOSH research and have shown a correlation with health risks in buildings that have indoor environmental complaints.

\section{Routine Visual Inspections}

Implementing periodic room inspections for dampness can help to identify trouble areas before they become major problems. For example, conducting observational inspections in buildings quarterly or two times per year (spring and fall) provides documentation of dry versus damp areas and helps to prioritize maintenance and repair. The NIOSH Dampness and Mold Assessment Tool is an easy and inexpensive way to track, record, and compare conditions over time. The assessment form and associated instructions are available on the NIOSH website at https://www.cdc.gov/niosh/docs/2019-115/ [NIOSH 2018]. Using moisture meters and infrared cameras can also sometimes identify sources of dampness.

\section{Remediation}

Wetted materials need to be dried within 48 hours of getting wet to prevent mold growth, and necessary repairs need to be made to prevent further water entry into the building. If mold is identified on materials, appropriate remediation guidelines with proper containment are recommended to minimize exposure to building occupants. The document, Guidelines on Assessment and Remediation of Fungi in Indoor Environments, developed by the New York City Department of Health and Mental Hygiene (NYCDH\&MH), provides guidance for cleaning mold-damaged materials (http:/www1.nyc.gov/assets/doh/downloads/pdf/epi/ epi-mold-guidelines.pdf ) [NYCDH\&MH 2008]. Inappropriate remediation (e.g., painting over water-damaged materials or moldy surfaces) can cause further problems with building degradation and symptoms in occupants.

\section{After Remediation}

After repairs and remediation are completed, employees and management often wish to know if the building is "safe." Building consultants often recommend and perform "clearance" air sampling after remediation work has been completed in an attempt to demonstrate that the building is safe for occupants. However, there is no scientific basis for the use of air sampling for this purpose. Once remediation is completed (moldy and damaged materials removed; musty odors no longer evident), the best evidence that the building is safe may be that employees no longer experience building-related symptoms. In large populations of workers, using employee health questionnaires may be helpful to collect information on building-related symptoms, particularly among persons new to the building after remediation 
(i.e., those without "sensitizing" historical exposures during a period of water damage). Unfortunately, even if most employees experience improvement in their symptoms, and new employees remain free of building-related symptoms, some employees with allergic conditions may not notice an improvement because their immune systems may continue to react to very small amounts of allergens. Such individuals may have to avoid the building even after an otherwise successful remediation. An individualized management plan (such as assigning an affected employee to a different work location, perhaps at home or a remote site) is sometimes required, depending upon medical findings and recommendations of the individual's physician.

NIOSH has evaluated numerous buildings and has found that, if building dampness is not neglected, these problems can generally be corrected using remediation practices (with appropriate containment to minimize exposure of building occupants) that are fairly standardized. The NIOSH (http://www.cdc.gov/niosh/topics/indoorenv/), EPA (http://www. epa.gov/iaq/), and OSHA (http://www.osha.gov/SLTC/indoorairquality/) websites have information on indoor environmental quality.

\section{Health Outcomes Following Remediation of Water-damaged Buildings}

Numerous studies have documented health outcomes following remediation of waterdamaged buildings. In some buildings, remediation has been followed by decreases in respiratory symptoms reported by occupants [Jarvis and Morey 2001; HaverinenShaughnessy et al. 2004; Meklin et al. 2005; Kercsmar et al. 2006; Lignell et al. 2007; Haverinen-Shaughnessy et al. 2008] and no new cases of respiratory illness [Jarvis and Morey 2001]. In other buildings, remediation has not resulted in improved health outcomes. Incomplete remediation is one possible explanation [Ebbehoj et al. 2002; Patovirta et al. 2004; Meklin et al. 2005; Haverinen-Shaughnessy et al. 2008; Iossifova et al. 2011]. Yet there is also evidence that remediation may be effective in terms of preventing new illness, but not eliminating symptoms in previously affected occupants [Haverinen-Shaughnessy et al. 2004]. For some employees, an individualized management plan (such as assigning an affected employee to a different work location, perhaps at home or a remote site) is required, depending upon medical findings and recommendations of the individual's physician.

\section{Building Ventilation and Indoor Environmental Quality}

Our walkthrough indicated the HVAC was improperly functioning based on blocked vents and the presence of the black particulates at most seams and vents throughout the building. Retrofitting the industrial building to an office building and having irregular occupancy density likely contributes substantially to the unbalanced HVAC system. Poor ventilation in buildings is a common problem and is frequently caused by lack of proper attention to the building's HVAC system. HVAC systems include all of the equipment used to ventilate, heat, and cool the building; to move the air around the building (ductwork); and to filter and clean the air. These systems can have a significant impact on how pollutants are distributed in and removed from spaces. They can even act as sources of pollutants in some cases, such as when ventilation air filters become contaminated with dirt and/or moisture, when microbial growth results from stagnant water in drain pans, or from uncontrolled moisture inside of air ducts. 


\section{Ventilation System Design}

The air delivery capacity requirements of an HVAC system are based in part on the projected number of people and the area of the occupied space. Proper distribution of ventilation air throughout all occupied spaces is essential. When areas in a building are used differently than their original purpose, the HVAC system may require modification to accommodate these changes. For example, if a storage area is converted into space occupied by people, the HVAC system may require alteration to deliver enough conditioned air to the space.

\section{Outdoor Air Supply}

Adequate supply of outdoor air, typically delivered through the HVAC system, is necessary in any office environment to dilute pollutants that are released by equipment, building materials, furnishings, products, and people. Carbon dioxide $\left(\mathrm{CO}_{2}\right)$ is a normal constituent of exhaled breath; thus, $\mathrm{CO}_{2}$ will also increase during building occupancy. $\mathrm{CO}_{2}$ levels are routinely collected in air quality studies because they can indicate whether a sufficient quantity of outdoor air is being introduced to an occupied space for acceptable odor control. The American National Standards Institute (ANSI) and ASHRAE have developed consensus standards and guidelines for HVAC systems. ASHRAE notes in an informative appendix to ANSI/ASHRAE Standard 62.1-2016: Ventilation for Acceptable Indoor Air Quality that indoor $\mathrm{CO}_{2}$ concentrations no greater than $700 \mathrm{ppm}$ above outdoor $\mathrm{CO}_{2}$ concentrations will satisfy a substantial majority (about 80\%) of occupants [ANSI/ASHRAE 2016]. This would typically correspond to indoor concentrations below $1200 \mathrm{ppm}$ since outdoor $\mathrm{CO}_{2}$ concentrations usually range from 375 to $500 \mathrm{ppm}$. However, $\mathrm{CO}_{2}$ is not an effective indicator of ventilation adequacy if the ventilated area is not occupied at its usual occupant density at the time the $\mathrm{CO}_{2}$ is measured. Elevated $\mathrm{CO}_{2}$ concentrations suggest that other indoor contaminants may also be increased. If $\mathrm{CO}_{2}$ concentrations are elevated, the amount of outdoor air introduced into the ventilated space may need to be increased.

In some cases, building owners/managers or occupants will open doors or windows to increase the amount of outdoor air coming into their building. However, relying on open doors may cause problems. For example, the air coming into the building through the doors may not reach all of the office areas in the building. The incoming air is unfiltered and may contain outdoor air pollutants such as pollen and dust. Additionally, open doors may affect the ability of the HVAC system to adequately control temperatures and humidity. ASHRAE guidelines provide specific details on ventilation for acceptable indoor environmental quality. A ventilation system expert can help meet ASHRAE ventilation guidelines in the building. ANSI/ASHRAE 62.1-2016 recommends outdoor air supply rates that take into account people-related sources as well as building-related sources. For office spaces, conference rooms, and reception areas, five cubic feet per minute $(\mathrm{cfm})$ of outdoor air per person $(\mathrm{cfm} /$ person) is recommended for people-related sources, and an additional $0.06 \mathrm{cfm}$ for every square foot $\left(\mathrm{cfm} / \mathrm{ft}^{2}\right)$ of occupied space is recommended to account for building-related sources. In elementary and high school classrooms, $10 \mathrm{cfm} /$ person plus $0.12 \mathrm{cfm} / \mathrm{ft}^{2}$ of outdoor air is suggested. To find rates for other indoor spaces, refer to Table 6.2.2.1 which is found in ANSI/ASHRAE 62.1-2016 [ANSI/ASHRAE 2016]. ASHRAE standards are generally incorporated into legally-enforceable building codes, including the International Mechanical Code, which is adopted by many states, cities, and municipalities as part of their 
building codes. Care should be taken to meet the ventilation requirements most appropriate for your locality and building type.

\section{Exhaust Rates}

For spaces where airborne contaminants and odors are prevalent, ANSI/ASHRAE 62.1-2016 offers minimum exhaust rates from the space. For copy and printing rooms, the standard recommends an exhaust rate of at least $0.5 \mathrm{cfm} / \mathrm{ft}^{2}$ directly outdoors. The makeup air for this exhaust air can consist of any combination of outdoor air, recirculated air, or air transferred from adjacent spaces. When normal dilution ventilation does not reduce occupant exposures to emissions from office equipment to acceptable levels, some form of local exhaust ventilation must be considered to remove the contaminant from the source before it can be spread throughout the occupied space. However, little scientific research has been done to develop and/or test the performance of local exhaust systems for typical office equipment.

\section{Outdoor Air Quality}

When present, outdoor air pollutants such as carbon monoxide, pollen, and dust may affect indoor conditions when outside air is taken into the building's ventilation system. Properly installed and maintained filters can trap many of the particles in outdoor supply air. Controlling gaseous or chemical pollutants may require more specialized filtration equipment and sometimes relocation of the outdoor air intakes. Section 4 of ANSI/ASHRAE Standard 62.1 specifies that any outdoor air brought into occupied spaces must be in compliance with the EPA's National Ambient Air Quality Standards (NAAQS). The standard further stipulates that a local outdoor air quality assessment should be conducted at a building and the immediate surroundings during periods the building is expected to be occupied to identify and locate contaminants of concern. If any outdoor contaminants exceed the NAAQS limits, the outdoor air must be appropriately treated prior to introduction of that air to the occupied spaces.

\section{Maintenance of HVAC Equipment}

Diligent maintenance of HVAC equipment is essential for the adequate delivery and quality of building air. All well-run buildings have preventive maintenance programs that help ensure the proper functioning of HVAC systems.

\section{HVAC Duct Cleaning}

We do not recommend duct cleaning unless it is found to be contaminated with mold or other irritant particles affecting the employees' health. Improper duct cleaning can release large amounts of dust and other contaminants into the work area. Fiberglass ductwork that has mold growth must be replaced; it cannot be cleaned. If metal duct cleaning is deemed necessary, it should only be performed by contractors who are members in good standing of the National Air Duct Cleaners Association. The National Institutes of Health (NIH) has a fact on duct cleaning available at http://www.ors.od.nih.gov/sr/dohs/Documents/ HVACDuctCleaning.pdf [NIH 2015].

Temperature and Relative Humidity

Management reported roughly five employee complaints daily concerning temperature or 
relatively humidity. Temperature and relative humidity measurements are often collected as part of an indoor environmental quality investigation because these parameters affect the perception of comfort in an indoor environment. The perception of thermal comfort is related to one's metabolic heat production, the transfer of heat to the environment, physiological adjustments, and body temperature. Heat transfer from the body to the environment is influenced by factors such as temperature, humidity, air movement, personal activities, and clothing. The ANSI/ASHRAE Standard 55-2017: Thermal Environmental Conditions for Human Occupancy specifies the combinations of indoor environmental and personal factors that produce acceptable thermal conditions to a majority of occupants within a space [ANSI/ASHRAE 2017]. Assuming slow air movement (less than 40 feet per minute) and $50 \%$ indoor relative humidity, the operative temperatures recommended by ASHRAE range from $68.5^{\circ} \mathrm{F}$ to $75^{\circ} \mathrm{F}$ in the winter, and from $75^{\circ} \mathrm{F}$ to $80.5^{\circ} \mathrm{F}$ in the summer. The difference in temperature ranges between the seasons is largely due to clothing selection. ASHRAE Standard 62.1 also recommends that indoor relative humidity be maintained at or below $65 \%$ for occupied spaces served by mechanical systems with dehumidification capability [ANSI/ASHRAE 2016]. For other mechanical system types or where spaces are not served by mechanical systems, Standard 62.1 has no humidity limitations. The EPA recommends maintaining indoor relative humidity between $30 \%$ and $50 \%$ to reduce mold growth [EPA $2017]$.

\section{Occupied and Non-occupied Settings}

This building contains a 24-hour crisis hotline and is therefore always occupied, but the callcenter only occupies a small part of the building after typical working hours. Buildings with simple HVAC systems often operate the ventilation system during occupied hours and then turn them off completely at night or other periods when the building is unoccupied. While turning the system off can save energy, depending on outdoor conditions, it often increases demand on the HVAC system when it is turned back on. Essentially, the equipment has to operate longer and harder to reach desired indoor temperature and humidity set-points. It can also create issues with condensation if temperatures indoors become warm during the "off" periods. This is particularly true in areas with warmer climates. More sophisticated HVAC systems with programmable thermostats or building automation systems allow for the ventilation equipment to be "set back" during unoccupied periods. This method still allows the indoor temperature and humidity to drift further from the occupied set-points, but eventually the HVAC system will come on to prevent fluctuations as extreme as they might otherwise be with the equipment powered off. This "set back" method still provides significant energy savings, but it does not require the system to work as long or as hard to bring the indoor conditions back to set-points in preparation for building occupancy. Whether the system runs continuously, is powered off during unoccupied periods, or is "set back" when empty, the indoor temperature and humidity conditions should always meet recommendations found in ANSI/ASHRAE 55-2017 and ANSI/ASHRAE 62.1-2016 any time the building is occupied.

\section{Dusty Environments, Carpeting, and Housekeeping}

During the walkthrough, we observed dust on surfaces throughout the building, including in areas near the HVAC system's supply air vents. There were many sources of dust including 
large stacks of paper that had to be stored for legal purposes and plants. A large amount of settled dust in occupied spaces is an indicator of potential indoor environmental quality problems. Dusty environments can be problematic especially when the dust is stirred-up and suspended into the air allowing dust particles to be inhaled. This can subsequently cause a reaction in some people, particularly those who suffer from dust allergies. Carpeted areas, upholstery, and areas with fleecy materials such as partitions or desk chairs may serve as reservoirs for accumulated dusts and are frequently associated with increased buildingrelated symptoms. We recommend attention to work area cleanliness by establishing a routine cleaning schedule. The floors and surface areas should be clutter free to allow for easier cleaning. If cleaning products are used when cleaning work areas, they should be used according to the manufacturer's directions.

Carpets may release volatile organic compounds (VOCs), especially when new or after treatments with chemicals, including biocides intended to control mold growth. Even with routine cleaning, carpets can accumulate dust and harbor dust mites that can cause allergic symptoms. In damp conditions, accumulated dusts may contain fungi and bacteria. It is important to keep the carpets clean with routine vacuuming with high-efficiency particulate air (HEPA) filters in order to not re-suspend dust. If you need to clean the carpet beyond HEPA filtered vacuuming, consider dry steam cleaning instead of carpet shampooing. Dry steam cleaning uses high temperature and low moisture vapor, usually below $6 \%$ of water content. Sufficient drying of the carpet is vital after any cleaning process.

NIOSH advises against the use of biocides to control microbial contaminants in indoor environments. Cleaning agents and sanitizers contain VOCs that are emitted into the air during and after cleaning, and can be circulated to other areas via the HVAC system. These VOC emissions may impact the environment and cause respiratory and dermal symptoms. Biocides, including fungicides and disinfectants, are chemical agents that destroy or harm living organisms. VOCs have their effect through inhalation, and volatile exposures from cleaning chemicals may be associated with symptoms in sensitive employees. Since exposure to some molds can result in respiratory health effects even when the molds are not viable (alive), hazardous exposures could continue even with biocide treatment.

Construction and renovation projects can create the release of airborne dusts, microbiological contaminants, gasses, and odors. Careful planning is essential to prevent exposures to building occupants. To protect employees from contaminants being released during construction and renovation, areas should be isolated using proper containment barriers. Additionally, construction areas should be negatively pressurized from occupied areas to prevent migration of contaminated air into employee workspaces. The NIOSH document entitled, Good Practice Guidelines for Maintaining Acceptable Indoor Environmental Quality During Construction and Renovation Projects [NIOSH 2007] and NIOSH website (http://www.cdc.gov/niosh/topics/indoorenv/ConstructionIEQ.html) have information on maintaining indoor environmental quality during construction and renovation activities.

\section{Rodent Droppings and Pest Control Program}

There were narrow dead spaces around the perimeter of the building that contained rodent 
traps, and there were known areas that would be problematic for rodents and other pests, associated with food sources. Animals or animal products such as dander, hair, fur, saliva, and body wastes contain allergens that can cause respiratory and skin disorders. The protein in urine from rats and mice is a potent allergen. When it dries, it can become airborne [EPA 2018a]. Many infectious diseases can also result from exposure to rodent feces and urine [CDC 2017]. An effective pest control program is the primary strategy for preventing human exposure to rodent diseases. This is achieved by cleanliness, eliminating food sources, sealing rodent entries into the work area, and trapping rodents in and around the workplace. The EPA recommends considering having HVAC ducts cleaned if they are infested with vermin (e.g., rodents, insects) [EPA 2018b]. For more information, the Centers for Disease Control and Prevention (CDC) provides guidance on preventing rodent infestation and cleaning up after rodents at http://www.cdc.gov/rodents/.

If not in place, a written pest control program should be developed. If a written program already exists, the pest control procedures should be assessed to determine if updates are needed. Important components of a written pest control program include procedures, recordkeeping materials, verification procedures, and frequency. Individuals responsible for each aspect of the program should be listed. If needed, pest control experts can evaluate the plan for completeness and effectiveness.

\section{Fragrances}

There have been some complaints about perfume odors. Several hundred different chemicals are used to make fragrances, many with little available health data. Fragranced products have been implicated in causing dermatologic problems and inducing or worsening respiratory problems including asthma and vocal cord dysfunction. Fragranced products are reported to trigger symptoms in individuals with asthma, hay fever, and migraines, even when the individuals are not "allergic" to fragrance ingredients. In a weighted random sample of the general population through telephone interviews, 30.5\% reported scented products irritating and $19 \%$ reported adverse health effects such as headaches and breathing problems [Caress and Steinemann 2009].

Many employers have established fragrance-free policies in their workplaces to protect their workers who are symptomatic when exposed to products that contain fragrances. These policies generally prohibit the use of the following types of scented products anywhere in their buildings: perfumes and colognes, deodorants, hairsprays, lotions and creams, potpourri, air fresheners, candles, scented soaps, cleaning chemicals, and any other fragrance-containing products. Use of soaps and cleaning products by janitorial staff can be limited to products that are fragrance-free or emit only low levels of volatile organic chemicals. Workers can also be encouraged to be as fragrance-free as possible upon arrival at the buildings, including not only the personal care products used on their skin, but also by avoiding use of scented detergents and fabric softeners on clothes worn to the building.

\section{Communication}

Through health hazard evaluations, NIOSH frequently finds a breakdown in communication between management and employees regarding building-related problems. Employees 
sometimes fear being singled out or fear repercussion from management or from other employees when they speak up about their concerns. Management typically has more success when they develop an anonymous environmental reporting system and when they establish an indoor environmental quality team consisting of a coordinator, representatives of the building employees, employers, and building management. The EPA's Indoor Air Quality Tools for Schools Action Kit provides guidelines on how to set up such a team and how to implement a program in a school setting which can be modified for your facility [EPA 2009]. These guidelines can be found on EPA's website at https://www.epa.gov/iaq-schools/ indoor-air-quality-tools-schools-action-kit. Clear procedures for recording and responding to concerns should be established to ensure adequate and timely response and to prevent small issues from becoming major health or comfort problems. Procedures should include the following:

- Log all complaints or problem reports

- Collect information about each complaint

- Ensure confidentiality

- Determine a plan for response

- Identify appropriate resources for response

- Apply remedial action

- Provide timely feedback to building occupants regarding the complaint and response actions

- Ensure remedial action has been effective

\section{Conclusions}

We identified potential issues related to indoor environmental quality at this office building, some of which were caused by retrofitting an industrial building into an office building. These issues included signs of a dusty environment, indoor dampness, improperly functioning HVAC system, and rodents and pests. Our limited sampling of dust surrounding the HVAC system could not determine if metals present on surfaces were from metals historically used to manufacture jewelry at this building.

\section{Recommendations}

On the basis of our findings, we recommend the actions listed below.

1. Maintain a communication system with employees for when building-related issues arise. Make sure to provide information on response actions to all employees, including posting exposure and environmental assessment reports. If not already formed, consider starting a health and safety committee that consists of employees, management, and maintenance. This can help increase communication between 
employees and management and help alleviate concerns.

2. Evaluate your existing housekeeping program with attention to keeping horizontal surfaces dust-free and carpet cleanliness.

a. Vacuum the carpet regularly with a vacuum equipped with a HEPA filter. Ensure HEPA vacuums are well-maintained and the HEPA filters are changed according to the manufacturer's recommendations.

b. Use a damp cloth or mop on nonporous surfaces rather than dry materials to clean up dust. This prevents dust from becoming airborne and resettling.

3. Follow the manufacturer's recommended maintenance schedules for the HVAC system, including replacing air filters, checking drip pans, ensuring thermostats are in working order, and checking and cleaning ventilation system dampers to ensure proper functioning.

4. Maintain indoor temperature and relative humidity levels according to the guidelines discussed.

5. Routinely inspect the building for water intrusion and damage and correct these upon discovery. During and after heavy rains, walk through the building and check for water incursion.

a. Identify any potential sources of dampness or mold through visual inspection and make proper repairs to prevent further problems from occurring.

b. If dampness or mold is not identified during visual inspections but is suspected because of musty odors or continued health complaints, consider other methods (e.g., infrared camera or borescope) to look for hidden problems.

c. Monitor repaired areas to ensure repairs and remedial actions are effective.

d. Keep a record of when and where mold or water-damaged materials are discovered and what has been done to promptly fix the underlying problem leading to the water damage.

6. Evaluate the content or enforcement of current rules or policies surrounding personal workspaces that could be contributing to indoor environmental quality concerns, including:

a. Acceptable locations for employee food preparation, storage, and consumption, including personal refrigerators and microwaves

b. Employee fish tanks

c. Fragrances in the workplace

7. Establish an individualized management plan to relocate employees (such as at home or a remote site) who are still suffering from health implications even after response actions have been taken.

8. Encourage employees to report new, persistent, or worsening symptoms, particularly those with a work-related pattern, to their healthcare providers and, as instructed by their employer, to a designated individual at their workplace. 


\section{Appendix A: Table}

Table A1. Summary of wipe samples analyzed for metals in particulates surrounding ventilation system at an office building

\begin{tabular}{|c|c|c|c|c|}
\hline Metal & LOD* $(\mu \mathrm{g})$ & $\mathrm{LOQ} \dagger(\mu \mathrm{g})$ & $\begin{array}{c}\text { No. positive } \\
\text { samples (\%) }\end{array}$ & $\begin{array}{c}\text { Mean (range) } \\
(\mu \mathrm{g})\end{array}$ \\
\hline Calcium & 10 & 35 & $25(100)$ & $1,115(46-5,800)$ \\
\hline Iron & 20 & 69 & $19(76)$ & $903(0-6,900)$ \\
\hline Zinc & 20 & 77 & $17(68)$ & $691(0-5,200)$ \\
\hline Potassium & 60 & 200 & $17(68)$ & $150(0-760)$ \\
\hline Magnesium & 9 & 31 & $19(76)$ & $130(0-790)$ \\
\hline Barium & 0.04 & 0.14 & $4(16)$ & $53(0-1,100)$ \\
\hline Phosphorus & 30 & 90 & $11(44)$ & $35(0-170)$ \\
\hline Copper & 2 & 5.7 & $18(72)$ & $21(0-240)$ \\
\hline Lead & 0.1 & 0.39 & $24(96)$ & $20(0-160)$ \\
\hline Titanium & 0.03 & 0.091 & $20(80)$ & $6.8(0-41)$ \\
\hline Zirconium & 0.01 & 0.044 & $22(88)$ & $6.0(0-56)$ \\
\hline Manganese & 0.1 & 0.32 & $21(84)$ & $6.0(0-33)$ \\
\hline Cobalt & 0.01 & 0.042 & $21(84)$ & $3.0(0-22)$ \\
\hline Chromium & 0.06 & 0.21 & $19(76)$ & $2.6(0-16)$ \\
\hline Strontium & 0.07 & 0.22 & $20(80)$ & $2.7(0-16)$ \\
\hline Nickel & 0.08 & 0.25 & $19(76)$ & $1.9(0-10)$ \\
\hline Vanadium & 0.02 & 0.58 & $16(64)$ & $1.2(0-7.8)$ \\
\hline Antimony & 1 & 3.8 & $4(16)$ & $0.8(0-9.2)$ \\
\hline Tin & 10 & 40 & $1(4)$ & $0.5(0-12)$ \\
\hline Silver & 0.02 & 0.077 & $19(76)$ & $0.4(0-3.3)$ \\
\hline Molybdenum & 0.05 & 0.15 & $17(68)$ & $0.2(0-1.7)$ \\
\hline Cadmium & 0.02 & 0.055 & $17(68)$ & $0.2(0-1.3)$ \\
\hline Yttrium & 0.004 & 0.012 & $19(76)$ & $0.2(0-1.2)$ \\
\hline Lithium & 0.03 & 0.089 & $19(76)$ & $0.2(0-0.9)$ \\
\hline Selenium & 0.3 & 1 & $14(56)$ & $0.2(0-0.6)$ \\
\hline Lanthanum & 0.03 & 0.11 & $5(20)$ & $0.1(0-0.6)$ \\
\hline Arsenic & 5 & 16 & 0 & - \\
\hline Beryllium & 0.005 & 0.016 & 0 & - \\
\hline Tellurium & 2 & 6.1 & 0 & - \\
\hline Thallium & 2 & 5.3 & 0 & - \\
\hline
\end{tabular}

Note: $\mu \mathrm{g}=$ micrograms

*Limit of detection

$\dagger$ Limit of quantification 


\section{Appendix B: Figures}

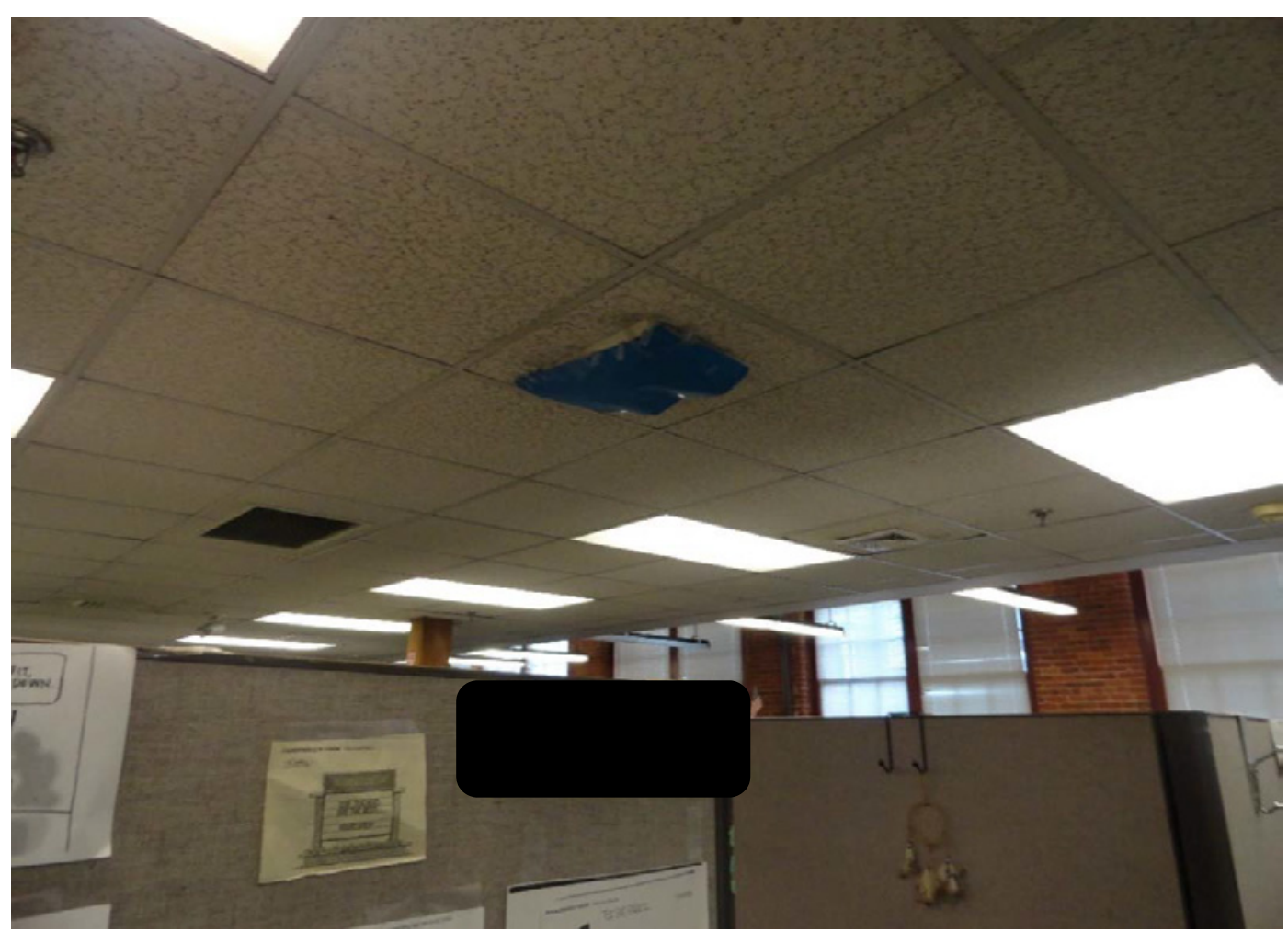

Figure B1. Vent blocked in personal workspace at office building on June 1, 2018. Photo by NIOSH.

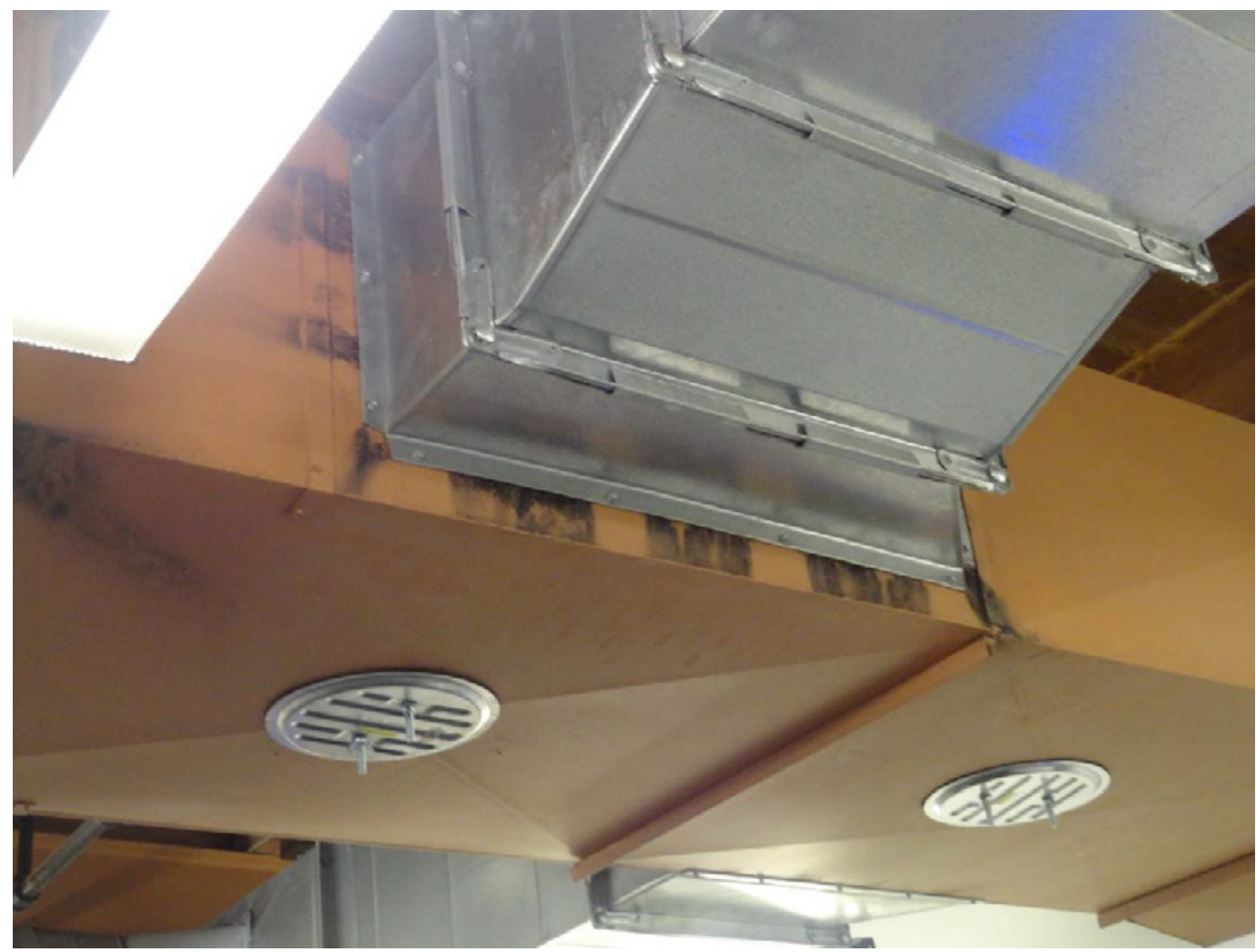

Figure B2. Example of black dust from heating, ventilation, and air-conditioning system at office building on June 1, 2018. Photo by NIOSH. 


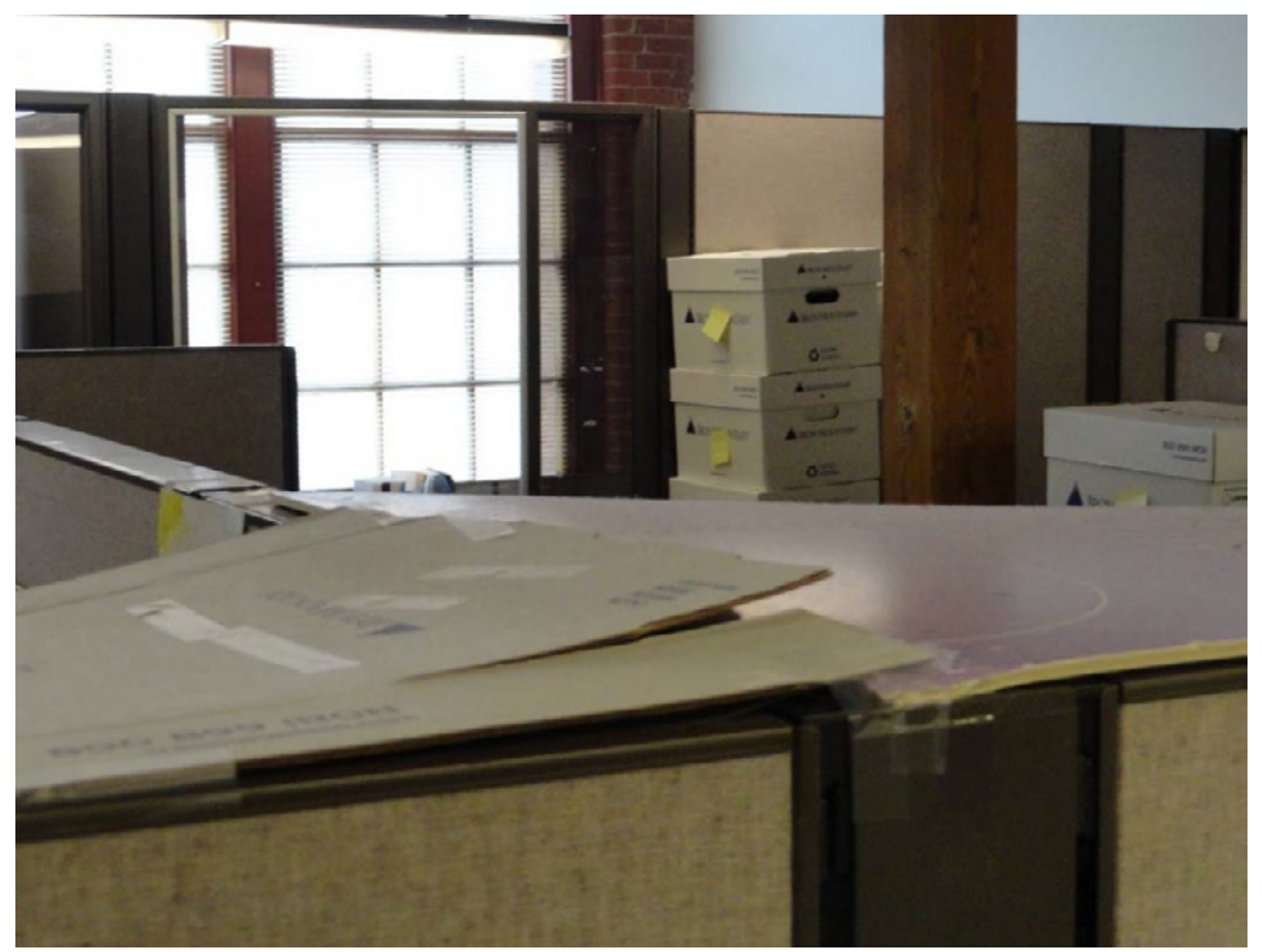

Figure B3. Personal workspaces partially covered with poster board to block dust from heating, ventilation, and air-conditioning system at an office building on June 1, 2018. Photo by NIOSH.

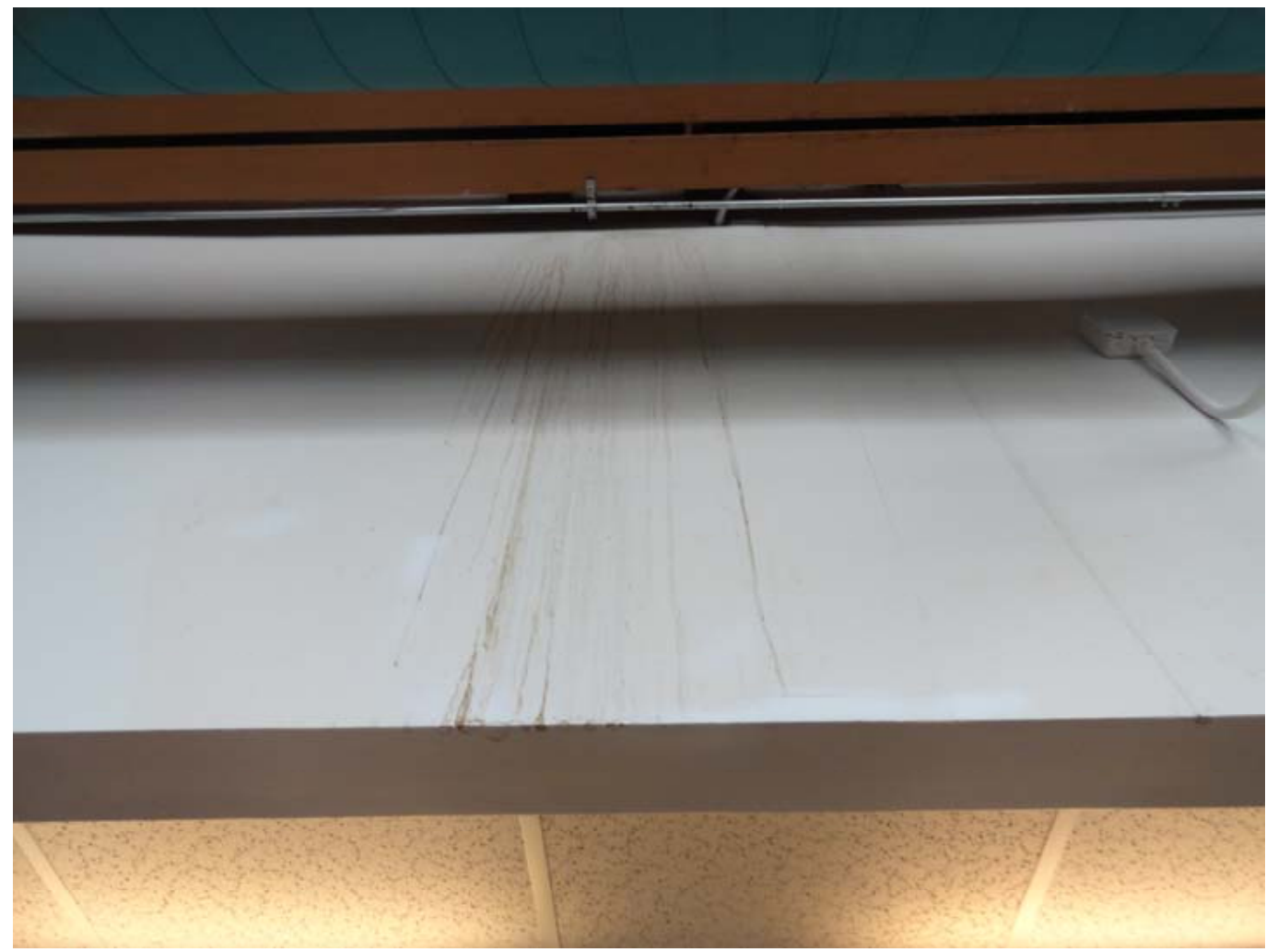

Figure B4. Evidence of recent water damage at an office building on June 1, 2018. Photo by NIOSH. 


\section{References}

ACGIH (American Conference of Governmental Industrial Hygienist) [2018]. 2018 TLVs ${ }^{\circledR}$ and BEIs ${ }^{\circledR}$ : Threshold limit values for chemical substances and physical agents and biological exposure indices. Cincinnati, OH: American Conference of Governmental Industrial Hygienists.

Al-Rajhi MA, Seaward MRD, Al-Aamar AS [1996]. Metal levels in indoor and outdoor dust in Riyadh, Saudi Arabia. Environ Int 22(3): 315-324.

ANSI (American National Standards Institute)/ASHRAE [2016]. Ventilation for acceptable indoor air quality, standard 62.1-2016. Atlanta, GA: ASHRAE.

ANSI/ASHRAE [2017]. Thermal environmental conditions for human occupancy, standard 55-2017. Atlanta, GA: ASHRAE.

ATSDR (Agency for Toxic Substances and Disease Registry) [1990]. Toxicological profile for Silver. Atlanta, GA: U.S. Department of Health and Human Services, Public Health Service. [https://www.atsdr.cdc.gov/ToxProfiles/tp146-c1-b.pdf] Date accessed: March 2019.

ATSDR [2005]. Toxicological profile for Nickel. Atlanta, GA: U.S. Department of Health and Human Services, Public Health Service [https://www.atsdr.cdc.gov/ToxProfiles/tp15c1-b.pdf]. Date accessed: March 2019.

ATSDR [2005b]. Toxicological profile for Tin. Atlanta, GA: U.S. Department of Health and Human Services, Public Health Service [https://www.atsdr.cdc.gov/ToxProfiles/tp55-c1-b. pdf]. Date accessed: March 2019.

ATSDR [2008]. Toxicological profile for Aluminum. Atlanta, GA: U.S. Department of Health and Human Services, Public Health Service [https://www.atsdr.cdc.gov/ToxProfiles/tp22c1-b.pdf]. Date accessed: March 2019.

ATSDR [2007]. Toxicological profile for Lead. Atlanta, GA: U.S. Department of Health and Human Services, Public Health Service [https://www.atsdr.cdc.gov/ToxProfiles/tp13-c1-b. pdf]. Date accessed: March 2019.

ATSDR [2012]. Toxicological profile for Manganese. Atlanta, GA: U.S. Department of Health and Human Services, Public Health Service [https:/www.atsdr.cdc.gov/ToxProfiles/ tp151-c1-b.pdf]. Date accessed: March 2019.

ATSDR [2017]. Toxicological profile for Antimony. Atlanta, GA: U.S. Department of Health and Human Services, Public Health Service [https://www.atsdr.cdc.gov/phs/phs. asp?id=330\&tid=58]. Date accessed: March 2019. 
Caress SM, Steinemann AC [2009]. Prevalence of fragrance sensitivity in the American population. Journal of environmental health 71(7):46.

CDC (Centers for Disease Control and Prevention) [2017]. Rodents [http://www.cdc.gov/ rodents/index.html]. Date accessed: March 2019.

DigitalFire [2015]. Titanium dioxide [https://digitalfire.com/4sight/hazards/ceramic hazard titanium dioxide_339.html] Date accessed: March 2019.

Ebbehoj NE, Hansen MO, Sigsgaard T, Larsen L [2002]. Building-related symptoms and molds: a two-step intervention study. Indoor Air 12(4):273-277.

EPA (Environmental Protection Agency) [2009]. Indoor air quality tools for schools action kit [https://www.epa.gov/iaq-schools/indoor-air-quality-tools-schools-action-kit]. Date accessed: March 2019.

EPA [2017]. The inside story: A guide to indoor air quality [http://www.epa.gov/indoor-air-quality-iaq/inside-story-guide-indoor-air-quality]. Date accessed: March 2019.

EPA [2018a]. Biological pollutants' impact on indoor air quality [https://www.epa.gov/indoor-air-quality-iaq/biological-pollutants-impact-indoor-air-quality]. Date accessed: March 2019.

EPA [2018b]. Should you have the air ducts in your home cleaned? [https://www.epa.gov/ indoor-air-quality-iaq/should-you-have-air-ducts-your-home-cleaned]. Date accessed: March 2019.

Faiz Y, Tufail M, Javed MR, Chaudhry MM, Siddique N [2009]. Road dust pollution of Cd, $\mathrm{Cu}, \mathrm{Ni}, \mathrm{Pb}$ and $\mathrm{Zn}$ along Islamabad Expressway, Pakistan. Microchem J 92(2):186-192.

Hassan SKM [2012]. Metal concentrations and distribution in the houseful, stairs, and entryway dust of some Egyptian homes. Atmos Environ 54:207-215.

Haverinen-Shaughnessy U, Pekkanen J, Nevalainen A, Moschandreas D, Husman T [2004]. Estimating effects of moisture damage repairs on students' health-a long-term intervention study. J Expo Anal Environ Epidemiol 14 Suppl 1:S58-S64.

Haverinen-Shaughnessy U, Hyvärinen A, Putus T, Nevalainen A [2008].Monitoring success of remediation: seven case studies of moisture and mold damaged buildings. Sci Total Environ 399(1-3):19-27.

IARC (International Agency for Research on Cancer) [2018]. Monographs on the identification of carcinogenic hazards to humans [https://monographs.iarc.fr/list-ofclassifications-volumes/]. Date accessed: March 2019. 
Iossifova YY, Cox-Ganser JM, Park JH, White SK, Kreiss K [2011]. Lack of respiratory improvement following remediation of a water-damaged office building. Am J Ind Med 54(4):269-277.

Jarvis JQ, Morey PR [2001]. Allergic respiratory disease and fungal remediation in a building in a subtropical climate. Appl Occup Environ Hyg 16(3):380-388.

Kercsmar CM, Dearborn DG, Schluchter M, Xue L, Kirchner HL, Sobolewski J, Greenberg SJ, Vesper SJ, Allan T [2006]. Reduction in asthma morbidity in children as a result of home remediation aimed at moisture sources. Environ Health Perspect 114(10):1574-1580.

Kettellarij J, Nilsson S, Midander K, Liden C, Julander A [2016]. Snapshot of cobalt, chromium and nickel exposure in dental technicians. Contact Dermatitis 75(6):370-376.

Latif MT, Saw MY, Saad A, Mohamad N, Baharuddin NH [2014]. Composition of heavy metals in indoor dust and their possible exposure: a case study of preschool children in Malaysia. Air Qual Atmos Health 7(2):181-193.

Lignell U, Meklin T, Putus T, Rintala H, Vepsäläinen A, Kalliokoski P, Nevalainen A [2007]. Effects of moisture damage and renovation on microbial conditions and pupils' health in two schools: a longitudinal analysis of five years. J Environ Monit 9(3):225-233.

Lioy PJ, Freeman NC, Millette JR [2002]. Dust: a metric for use in residential and building exposure assessment and source characterization. Environ Health Persp 110 (10):969-983.

MedlinePlus [2015]. Minerals [https://medlineplus.gov/minerals.html\#summary]. Date accessed: March 2019.

Meklin T, Potus T, Pekkanen J, Hyvärinen A, Hirvonen MR, Nevalainen A [2005]. Effects of moisture-damage repairs on microbial exposure and symptoms in school children. Indoor Air 15 Suppl 10:40-47.

Mendell MJ, Mirer AG, Cheung K, Tong M, Douwes J [2011]. Respiratory and allergic health effects of dampness, mold and dampness-related agents: a review of the epidemiologic evidence. Environ Health Perspect 119(6):748-756.

NIH (National Institutes of Health) [2015]. DOHS fact sheet on HVAC duct cleaning. Division of Occupational Health and Safety, Office of Research Services, National Institutes of Health [http://www.ors.od.nih.gov/sr/dohs/Documents/HVACDuctCleaning.pdf]. Date accessed: March 2019.

NIOSH (National Institute for Occupational Safety and Health) [1994]. Health hazard evaluation report: State of Rhode Island Department of Employment and Training. By Kaiser, EA and Sylvain, DC. Boston, MA. U.S. Department of Health and Human Services, Centers for Disease Control and Prevention, National Institute for Occupational Safety and Health, NIOSH HHE Report No. 93-0511. 
NIOSH [2003]. NIOSH manual of analytical methods $\left(\mathrm{NMAM}^{\circledR}\right) .4$ th ed. Schlecht PC, O'Connor PF, eds. Cincinnati, OH: U.S. Department of Health and Human Services, Centers for Disease Control and Prevention, National Institute for Occupational Safety and Health, DHHS (NIOSH) Publication 94-113 (August 1994); 1st Supplement Publication 96-135, 2nd Supplement Publication 98-119; 3rd Supplement 2003-154 [http://www.cdc.gov/niosh/ docs/2003-154/]. Date accessed: March 2019

NIOSH [2007]. Indoor environmental quality information: Good practices guidelines for maintaining acceptable indoor environmental quality during construction and renovation. NIOSH (HETAB) No. 503 [http://www.peer.org/assets/docs/doi/05_21_12 niosh.pdf]. Date accessed: March 2019.

NIOSH [2010]. NIOSH pocket guide to chemical hazards. Cincinnati, OH: U.S. Department of Health and Human Services, Centers for Disease Control and Prevention, National Institute for Occupational Safety and Health, DHHS (NIOSH) Publication No. 2010-168c [http://www.cdc.gov/niosh/npg/]. Date accessed: March 2019.

NIOSH [2012]. NIOSH Alert: Preventing occupational respiratory disease from exposures caused by dampness in office buildings, schools, and other nonindustrial buildings. DHHS (NIOSH) Publication No. 2013-102 [http://www.cdc.gov/niosh/docs/2013-102/]. Date accessed: March 2019.

NIOSH [2018]. Dampness and mold assessment tool for general buildings - Form \& instructions. Cox-Ganser J, Martin M, Park JH, Game S. Morgantown WV: U.S. Department of Health and Human Services, Centers for Disease Control and Prevention, National Institute for Occupational Safety and Health, DHHS (NIOSH) Publication No. 2019-115 [https://www.cdc.gov/niosh/docs/2019-115/]. Date accessed: March 2019.

NYCDH\&MH (New York City Department of Health and Mental Hygiene) [2008]. Guidelines on assessment and remediation of fungi in indoor environments [http://www1.nyc.gov/assets/doh/downloads/pdf/epi/epi-mold-guidelines.pdf]. Date accessed: March 2019.

OSHA (Occupational Safety and Health Administration) [1993]. Compliance and enforcement activities affected by the PELs decision. August 5, 1993 Memorandum. [https:// www.osha.gov/pls/oshaweb/owadisp.show document?p table=INTERPRETATIONS\&p $\underline{\mathrm{id}=21220] .}$. Date accessed: March 2019.

OSHA [2003]. Enforcement policy for respiratory hazards not covered by OSHA permissible exposure limits. January 24, 2003 Memorandum. [https://www.osha.gov/pls/oshaweb/ owadisp.show document?p table=INTERPRETATIONS\&p id=24749]. Date accessed: March 2019.

OSHA [2018]. Permissible exposure limits - annotated tables [https://www.osha.gov/dsg/ annotated-pels/index.html]. Date accessed: March 2019. 
Patovirta RL, Husman T, Haverinen U, Vahteristo M, Uitti JA, Tukiainen H, and Nevalainen A [2004]. The remediation of mold damage school - a three year follow-up study on teacher's health. Cent Eur J Public Health 12(1):36-42.

Rings \& Things [2018]. About metals: Information for making jewelry [http://www.ringsthings.com/Learn/Metals/]. Date accessed: March 2019.

Sandborn MD, Abelsohn A, Campbell M, Weir E [2002]. Identifying and managing adverse environmental health effects: 3. Lead exposure. CMAJ 166 (10):1287-1292.

Tran DT, Alleman LY, Coddeville P, Gallo JC [2012]. Elemental characterization and source identification of size resolved atmospheric particles in French classrooms. Atmos Environ $54: 250-9$.

Wittman R, Hu H [2002]. Cadmium exposure and nephropathy in a 28-year-old female metals worker. Environ Health Persp 110(12):1261-1266.

WHO (World Health Organization) [2009]. WHO guidelines for indoor air quality: dampness and mould [http://www.who.int/airpollution/guidelines/dampness-mould/en/]. Date accessed: March 2019. 
This page left intentionally blank 
Keywords: NAICS 923130 (Services), Rhode Island, heavy metals, mold, indoor environmental quality 
The Health Hazard Evaluation Program investigates possible health hazards in the workplace under the authority of the Occupational Safety and Health Act of 1970 (29 U.S.C. $§ 669$ (a) (6)). The Health Hazard Evaluation Program also provides, upon request, technical assistance to federal, state, and local agencies to invest igate occupational health hazards and to prevent occupational disease or injury. Regulations guiding the Program can be found in Title 42, Code of Federal Regulations, Part 85; Requests for Health Hazard Evaluations (42 CPR Part 85).

\section{Disclaimer}

The recommendations in this report are made on the basis of the findings at the workplace evaluated and may not be applicable to other workplaces.

Mention of any company or product in this report does not constitute endorsement by the National Institute for Occupational Safety and Health (NIOSH).

Citations to Web sites external to NIOSH do not constitute NIOSH endorsement ofthe sponsoring organizations or their programs or products. NIOSH is not responsible for the content of these Web sites. All Web addresses referenced in this document were accessible as of the publication date.

\section{Acknowledgments}

Desktop Publisher: Tia McClelland

Site Visit Team Members: Reid Harvey and Karl Feldmann

\section{Availability of Report}

Copies of this report have been sent to the employer, employees, and union at the facility. The state and local health department and the Occupational Safety and Health Administration Regional Office have also rece ived a copy. This report is not copyrighted and may be freely reproduced.

This report is available at https://www.cdc.gov/niosh/hhe/reports/pdfs/2018-0046-3346.pdf.

All other HHE Reports may be found at https://www2a.cdc.gov/hhe/search.asp

\section{Recommended citation for this report:}

$\mathrm{NIOSH}$ [2019]. Health hazard evaluation report: evaluation of indoor environmental quality with limited surface sampling for metals at an office building. By Harvey RR. Morgantown, WV: U.S. Department of Health and Human Services, Centers for Disease Control and Prevention, National Institute for Occupational Safety and Health, NIOSH HHE Report No. 2018-0046-3346. 
Delivering on the Nation's promise:

Safety and health at work for all people through research and prevention

To receive documents or other information about occupational safety and health topics, contact NIOSH

Telephone: 1-800-CDC-INFO (1-800-232-4636)

TTY: 1-888-232-6348

email: cdcinfo@cdc.gov

or visit the NIOSH website at http://www.cdc.gov/niosh

SAFER • HEALTHIER • PEOPLE ${ }^{\text {TM }}$ 